\title{
ANALISIS ASPEK PASAR DAN PEMASARAN
}

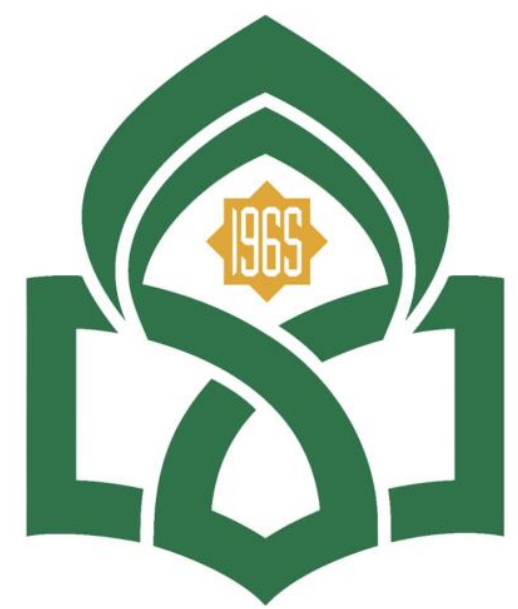

UNIVERSITAS ISLAM NEGERI

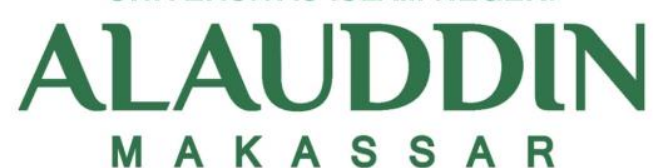

M A K A S S A R

Disusun Oleh:

Rahmadana

90500120025

PERBANKAN SYARIAH

FAKULTAS EKONOMI DAN BISNIS ISLAM

UNIVERSITAS ISLAM NEGERI ALAUDDIN MAKASSAR

$2021 / 2022$ 


\section{KATA PENGANTAR}

Puji syukur kami panjatkan kehadirat Tuhan yang Maha Esa. Atas rahmat dan hidayah-Nya, penulis bisa menyelesaikan makalah studi kelayakan bisnis yang berjudul "Analisis Aspek Pasar dan Pemasaran".

Tak lupa penulis mengucapkan terimah kasih kepada semua pihak yang telah membantu dan berkontribusi dalam menyelesaikan makalah ini.

Penulis menyadari ada kekurangan pada penulisan makalah ini. Oleh sebab itu, saran dan kritik senantiasa diharapkan demi perbaikan karya penulis. Penulis juga berharap semoga makalah ini mampu memberikan pengetahuan kepada khalayak luas.

Gowa, 08 November 2021

Penulis 


\section{DAFTAR ISI}

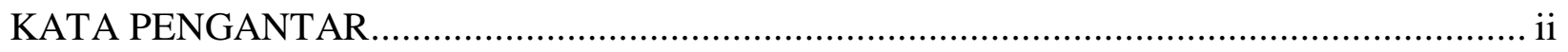

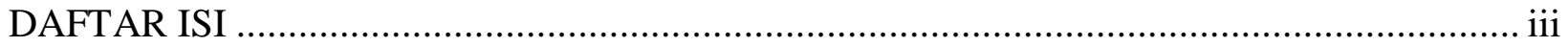

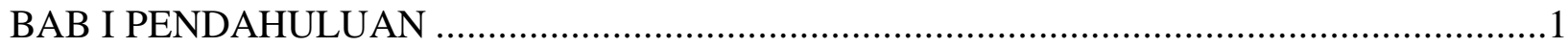

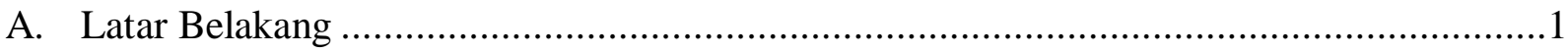

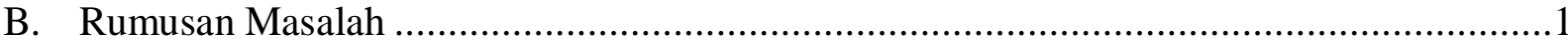

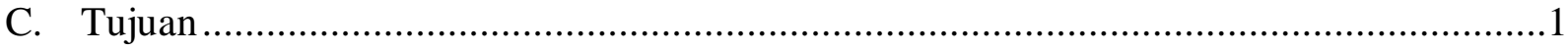

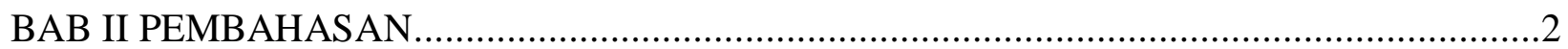

A. Pengertian Aspek Pasar dan Pemasaran ..................................................................

B. Tujuan Analisis Aspek Pasar dan Pemasaran .........................................................4

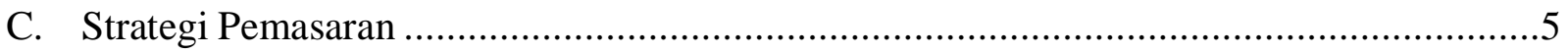

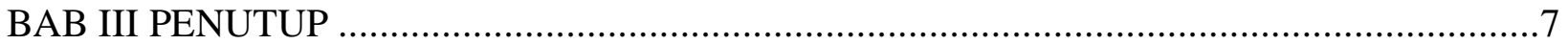

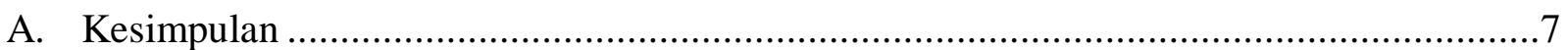

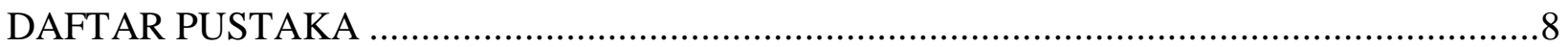




\section{BAB I \\ PENDAHULUAN}

\section{A. Latar Belakang}

Di indonesa banyak sekali perusahaan atau lembaga yang bersaing dengan beragam inovasi untuk mengembangkan usahanya agar lebih maju. Dalam suatu perusahaan dibutuhkan banyak pertimbangan untuk keuntungan dan proft yang didapatkan lebih banyak daripada modal yang dikeluarkan namun dengan kualitas yang terjamin.

Pasar merupakan tempat bertemunya penjual dan pembeli untuk melakukan transaksi. Dalam studi kelayakan bisnis aspek pasar merupakan aspek yang berkaitan dengan kondisi pasar dari bidang industri yang dijalankan oleh sebuah bisnis, yang dianalisa biasanya akan meliputi permintaan pasar tehadap produk yang akan dijual, tingkat persaingan dan strategi pesaing dalam memasarkan produk, dan segmentasi pasar. Aspek pasar dan pemasaran menjadi hal penting yang perlu diperhatikan dalam studi kelayakan bisnis, karena aspek tersebut nantinya dapat membantu sebuah bisnis utnuk menentukan arah dan tujuan serta sasaran pemasaran dari produk yang akan ditawarkan.

Pentingnya aspek pasar dan pemasaran dalam suatu bisnis yaitu dimana dalam suatu aspek pasar dan pemasaran digunakan untuk mengetahui seberapa besar permintaan yang ada sehingga bisnisnya dapat berjalan sesuai dengan apa yang diinginkan. Persaingan yang ketat membuat analisis aspek pasar dan pemasaran sangat dibutuhkan untuk mengurangi resiko-resiko yang dapat merugikan bisnis atau perusahaan.

\section{B. Rumusan Masalah}

1. Apa pengertian dari aspek pasar dan pemasaran?

2. Apa tujuan dari analisis aspek pasar dan pemasaran?

3. Bagaimana strategi dan cara menerapkan analisis aspek pasar dan pemasaran?

\section{Tujuan}

Dari rumusan masalah diatas didapatkan tujuan dari makalah ini, yaitu :

1. Untuk mengetahui pengertian dari aspek pasar dan pemasaran.

2. Untuk mengetahui tujuan dari analisis pasar dan pemasaran.

3. Untuk mengetahui strategi dan cara menerapkan analisis aspek pasar dan pemasaran 


\section{BAB II \\ PEMBAHASAN}

\section{A. Pengertian Aspek Pasar dan Pemasaran}

Pasar dan pemasaran merupakan rangkaian yang tidak bisa dipisahkan satu sama lain. Pasar dan pemasaran saling ketergantungan dan saling mempengaruhi satu sama lain, sehingga pasar akan selalu berrdampingan pleh pemasaran dan seriap kegiatan pemasaran adalah untuk menciptakan pasar.

Dalam artian sempit pasar dapat diartikan sebagai tempat bertemunya para penjual dan pembeli untuk melakukan transaksi, dengan kata lain bahwa pasar memiliki tempat atau lokasi tertentu sehingga memungkinkan penjual dan pembeli untuk melakukan transaksi. Sedangkan secara luas pasar adalah himpunan pembeli nyata dan pembeli potensial atas suatu produk. Dengan kata lain, bahwa pasar mengandung arti kumpulan atau himpunan para pembeli baik itu pembeli nyata maupun pembeli potensial atas jasa atau produk yang dibeli (Kasmir and Jakfar 2013).

Analisis aspek pasar dan pemasaran adalah suatu usulan proyek yang ditujukan untuk mendapatkan gambaran mengenai besar pasar potensial yang tersedia dan mengurangi kemungkinan resiko yang akan terjadi untuk masa yang akan datang (Suprapto 2013).

\section{Aspek Pasar}

Dalama study kelayakan bisnis dan investasi, Aspek pasar secara garis besar membahas tentang seberapa besar permintaan, penawaran serta harga dari suatu produk. Adapun metode yang digunakan selama beberapa tahun kedepan dalam melakukan permintaan dan penawaran ialah metode proyeksi yang bertujuan untuk mengetahui sejauh mana ataupun seberapa besar tingkat penyerapan pasar. Ada beberapa hal yang perlu diketahui dan dipelajari dalam aspek pasar ini, antara lain:

a. Penawaran; yakni kuantitas barang yang itaearkan pada berbagai tingkatan harga pasar. Apabila harga dari suatu barang tertentu mengalami peningkatan, maka kuantitas dari barang tersebut juga akan semakin tinggi, begitupun sebaliknya.

b. Permintaan; Yaitu jumlah barang yang dibutuhkan oleh konsumen yang memiliki kemampuan membeli barang dengan berbagai tingkat harga. Apabila harga suatu barang mengalami peningkatan, maka kuantitas dari barang yang diminta akan 
mengalami penurunan, demikian pula sebaliknya. Apabila harga barang yang diminta semakin menurun maka kuantitas barang yang diminta akan semakin naik.

c. Bentuk Pasar; Jika dilihat dari segi produsen, maka pasar dapat dibedakan menjadi 4 yakni pasar persaingan sempurna, pasar oligopoly, pasar monopoli dan pasar persaingan monopolistis. Sedangkan jika ditinjau dari segi konsumen, pasar dibedakan menjadi pasar pemerintah, pasar industry, pasar reseller (penjual kembali) dan pasar konsumen.

d. Mengukur serta meramalkan permintaan; yaitu seni memperkirakan kemungkinankemungkinan yang akan terjadi dimasa mendatang di saat sekarang dengan cara melakukan riset dan pengumpulan data serta informasi dari masa lampau, ke udian melakukan pengolahan data, kemudian menentukan metode peramalan, sebelum kemudian memproyeksikan hasil data yang telah diperoleh hingga melakukan pengamblan keputusan peramalan dengan metode regresi (Metode ramalan yang disusun atas dasar pola data dari masa lampau)

\section{Aspek Pemasaran}

Pemasaran merupakan suatu proses sosial dan manajerial yang mana baik individu maupun kelompok dapat memperoleh apa yang mereka inginkan ataupun butuhkan dengan cara melakukan pertukaran produk maupun nilai dengan pihak yang lainnya. Beberapa hal pokok yang penting untuk dianalisis dalam aspek pemasaran ialah:

a. Segmentasi pasar; yakni pembagian pasar kedalam beberapa kelompok pembeli yang berbeda yang tentunya mempunyai atau memerlukan produk dan marketing mix yang juga berbeda. Beberapa aspek seperti geografis, demografi, psikografis, dan perilaku merupakan bebrapa aspek utama didalam mensegmentaskan pasar

b. Sasaran pasar analisis; Dapat dilakukan dengan cara menelaah tiga faktor prnting dalam aspek pemasaran yakni: Ukuran dan pertumbuhan segmen, Kemenarikan structural segmen, serta Sasaran dan sumber daya.

c. Menentukan posisi pasar; dapat dilakukan dengan mengikuti tiga langkah yakni Mengidentifikasi keunggulan kompetitif, Memilih keunggulan kompetitif, serta Mewujudkan dan mengkomunikasikan posisi.

d. Analisis persaingan pasar didalam menetapkan strategi pemasaran kompetitif yang efektif; dalam studi kelayakan bisnis, tentunya perlu bagi kita untuk mencermati produk, 
harga, saluran distribusi dan juga promosi yang dilakukan oleh para pesaing terdekat. Beberapa tahap atau langkah yang bisa kita tempuh dalam menganalisis para pesaing, antara lain: Menidentifikasi para pesaing, Menentukan sasaran para pesaing, serta Mengidentifikasi para pesaing (Yanuar 2016).

\section{B. Tujuan Analisis Aspek Pasar dan Pemasaran}

Analisis aspek pasar dan pemasaran sangatlah penting dalam menentukan sasaran sehingga dapat ditargetkan melalui berbagai strategi pemasaran yang dirancang dan akan diterapkan kedepannya. Perusahaan yang sukses haruslah menggunakan analisis pemasaran dengan strategi yang baik sehingga mencapai tujuan yang diinginkan, strategi ini pun bisa bersifat jangka pendek, menengah, hingga jangka panjang sesuai dengan strategi perencanaan yang dibangun. Pemasaran berperan untuk mencapai keuntungan dengan menciptakan hubungan dengan menciptakan hubungan dengan pelanggan yang berkelanjutan berdasarkan kepuasan pelanggan (Rostwentivaivi and Fizriani 2019).

Menurut Kasmir dan Jakfar (Afiyah, Saifi and Dwiatmanto 2015), tujuan utama dari aspek pasar dan pemasaran yaitu untuk mengetahui berapa besar pasar yang akan dimasuki, strktur dan peluang yang ada serta prosepekmpasar, hingga bagaimana strategi pemasaran yang harus dilakukan. Secara khusus perusahaan atau organisasi membuat analisis pasar dan pemasaran dengan tujuan untuk:

1. Meningkatkan laba dan penjualan, yaitu cara sebuah perusahaan atau organisasi memperbanyak omset dari setiap penjualan, maka akan didapatkan laba atau keuntungan sesuai dengan target dan perencanaan dari suatu perusahaan

2. Mendominasi pasar, yaitu cara perusahaan bagaimana untuk mendominasi pasar dengan cara meningkatkan dan memperluas market share-nya dibeberapa wilayah tertentu.

3. Memperkecil daftar pesaing, yaitu suatu cara yang digunakan untuk memperkecil kemungkinan adanya pesaing dibidang yang sama dan memiliki produk yang sejenis yang dapat menyaingi atau bahkan membuat perusahaan atau usaha menjadi tidak dilirik oleh masyarakat. Untuk menghindari hal tersebut perusahaan harus menciptkatan poduk dengan mutu yang tinggi namun dengan harga yang masih terjangkau dan tidak terlalu mahal dikalangan masyarakat menengah. 
4. Menaikkan prestise produk dan perusahaan dipasar, dengan cara membuat promosi yang menarik bagi pelanggan. Selain itu juga dapat dilakukan peningkatan mutu produk yang sesuai dengan keinginan konsumen.

5. Memenuhi pihak-pihak tertentu, tujuan ini lebih mengarah pada puhak-pihak tertentu seperti pemerintah ataupun lembaga tertentu (Kasmir and Jakfar 2013).

\section{Strategi Pemasaran}

Dalam studi kelayakan bisnis dalam hal ini analisis aspek pasar dan pemasaran bahwa untuk menciptakan pasar yang baik dan stabil maka diperlukan untuk merancang dan membuat sebuah strategimdemi menghasilakan pemasaran yang baik pula, serta efekti dan efisien untuk mencapai target pasar yang diinginkan perusahaan (Rostwentivaivi and Fizriani 2019).

Salah satu strategi yang digunakan dalam aspek pasar dan pemasaran adalah bauran pemasaran (marketing mix) yang terdiri dari 4P (Product, price, place, dan promotion).

\section{Product (produk)}

Produk adalah barang yang diproduksi untuk mencukupi kebutuhan konsumen. Produk bisa berwujud dan bisa tidak berwujud dikarenakan produk bisa berupa barang ataupun jasa. Menurut (Musfar 2020), suatu produk memiliki siklus hidup tertentu yang mencakup fase pertumbuhan, fase kematangan, dan fase penurunan penjualan. Secara sederhana ada beberapa yang menjadi pertanyaan yang harus dijawab perusahaan dalam membuat dan merancang sebuah produk, yaitu:

a. Apa keinginan konsumen terhadap layanan atau barang/produk?

b. Bagaimana konsumen menggunakan produk?

c. Dimana konsumen bisa menggunakan produk?

d. Layanan atau fitur yang dimiliki produk sehingga konsumen harus menggunakan atau memiliki produk tersebut?

e. Apakah ada layanan/ fitur yang mungkin kita lupa atau lewatkan?

f. Apakah ada layanan/ fitur yang dibuat yang tidak sesuai dengan kebutuhan?

g. Apa nama produknya sehingga dapat menarik dan mudah diingat oleh konsumen?

h. Apa yang membedakan produk tersebut dengan produk lain?

2. Price (harga) 
Harga adalah jumlah yang harus dibayar konsumen untuk dapat emenikmati produk yang ditawarkan. Ada tiga strategi dalam penetapan harga, yaitu; harga terobosan pasar, pasar menggelapkan harga, dan harga netral.

3. Place (tempat)

Perusahaan harus mengetahui cara memposisikan tempat agar bisa mendistribusikan produknya segingga dapat dijangkau dengan mudah oleh pembeli potensial. Ada tiga strategi didalam mendistribusikan produk, yaitu; distribusi intensif, distribusi eksklusif, dan distribusi selektif.

\section{Promotion (promosi)}

Promosi adalah hal yang penting dimana peusahaan harus mampu menarik perhatian para pembeli potensial sehingga dapat meningkatkan brand dan penjualan. Ada beberapa elemen dalam mempromosikan produk, yaitu:
a. Periklanan
b. Promosi penjualan
c. Hubungan sosial
d. Publisitas
e. Sponsor
f. Penjualan langsung 


\section{BAB III \\ PENUTUP}

\section{A. Kesimpulan}

Berdasarkan rumusan masalah dari isi dari makalah ini dapat ditarik kesimpulan sebagai berikut:

1. Analisis aspek pasar dan pemasaran adalah suatu usulan proyek yang ditujukan untuk mendapatkan gambaran mengenai besar pasar potensial yang tersedia dan mengurangi kemungkinan resiko yang akan terjadi untuk masa yang akan datang.

2. Tujuan aspek pasar dan pemasaran yaitu, Meningkatkan laba dan penjualan, Mendominasi pasar, Memperkecil daftar pesaing, Menaikkan prestise produk dan perusahaan dipasar, dan Memenuhi pihak-pihak tertentu.

3. Strategi yang digunakan dalam aspek pasar dan pemsaran adalah bauran pemasaran (marketing mix) yang terdiri dari 4P (Product, price, place, dan promotion) 


\section{DAFTAR PUSTAKA}

Afiyah, Abidatul, Muhammad Saifi, and Dwiatmanto. "Analisis Studi Kelayakan Usaha Pendirian Home Industry." Jurnal Administrasi Bisnis 23, no. 1 (2015): 1-11.

Kasmir, and Jakfar. Studi Kelayakan Bisnis Edisi Revisi. Jakarta: Kencana, 2013.

Musfar, Tengku Firli. Buku Ajar Manajemen Pemasaran Bauran Pemasaran Sebagai Materi Pokok dalam Manajemen Pemasara. Bandung: Medis Sains Indonesia, 2020.

Rostwentivaivi, Vela, and Atia Fizriani. "Kelayakan Bisnis ddan Pemasaran Tahu Jojoh di Kecamatan Karangpawitan, Kabupaten Garut." Jurnal Dedikasi Masyarakat 3, no. 1 (2019): 59-67.

Suprapto, Agus. "Analisis Aspek Pasar dan Pemasaran Pendirian Industri Dodol Salak Skala Kecil di Kabupaten Banjarnegara." Analisis Aspek Pasar dan Pemasaran 15, no. 1 (2013): 60-68.

Yanuar, Dony. "Analisis Kelayakan Bisnis Ditinjau dari Aspek Pasar, Aspek Pemasaran dan Aspek Keuangan pada UMKM Makanan Khas Bangka di Kota." Jurnal E- KOMBIS 2, no. 1 (2016): 41-51. 